\title{
Lumbosacral plexus in Brazilian Common Opossum
}

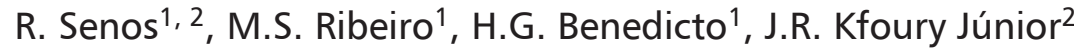 \\ ${ }^{1}$ Department of Morphology, Universidade Federal Fluminense, Niteroi, RJ, Brazil \\ 2Section of Anatomy of the Domestic and Wild Animals, Faculty of Veterinary Medicine and Zootechinics, \\ Universidade de São Paulo, SP, Brazil
}

[Received: 30 July 2015; Accepted: 20 September 2015]

The opossum has been suggested as an animal model for biomedical studies due to its adaptability to captivity and number of births per year. Despite many studies on morphology and experimental neurology using this opossum model, the literature does not offer details of the nerves of the lumbosacral plexus in this species. Ten lumbosacral plexus were dissected to describe the peripheral innervations of the Brazilian Common Opossum (Didelphis aurita) and compare the results with Eutheria clade species. The tensor fasciae latae muscle was absent and there was only one sartorius muscle for each limb. The distribution of the nerves were similar to other mammals, except for the caudal gluteal nerve, sartorius muscle innervations and the position of the pudendal nerve which arose from the major ischiatic foramen together with the ischiatic nerve, the cranial gluteal nerve and the caudal gluteal nerve. No anatomical variation was found. The special position of the pudendal nerve suggested that the Brazilian Common Opossum is a better model than rats or rabbits in surgical procedures with that specific nerve. In addition, the study revealed that the pelvic limb nerves are not an invariable structure of reference for muscle homology and homonym as reported previously. New investigation using other species of opossums are necessary to best comprehend the lumbosacral plexus distribution in the Methatheria clade and to confirm that other opossum species is eligible as a good model for pudendal nerve studies. (Folia Morphol 2016; 75, 3: 300-305)

Key words: anatomy, black-eared opossum, ischiatic, nerve, nervous system, pelvic limb

\section{INTRODUCTION}

The Brazilian Common Opossum (Didelphis aurita) is a South American opportunist, nocturnal, semiterrestrial, omnivorous marsupial $[1,4,5,8,13]$. This species is distinguished from other regional opossums by its naked black ears [13]. The Brazilian Common Opossum is widely spread in Brazil - especially in the Atlantic Forest and Restinga - Argentina and Paraguay. Ecologically, it attracted special attention due to its capacity to adapt to different conditions and to persist forest fragmentation in advance of the creations of urban areas [12, 13, 22, 32, 38, 41].

Due to its great adaptability to changing habitats and number of births, the opossum has been suggested to be used as laboratory animal model $[20,30]$. In addition, the opossums belong to the Methatheria clade, which was distinguished from Eutheria clade during the evolution process. Methatherian species

Address for correspondence: Dr R. Senos, Department of Morphology, Universidade Federal Fluminense, Rua Prof Hernani de Melo, 101 CEP 24210-130 Niteroi, RJ, Brazil, tel: +55 21 99760220, e-mail: rafaelsenos@yahoo.com.br 

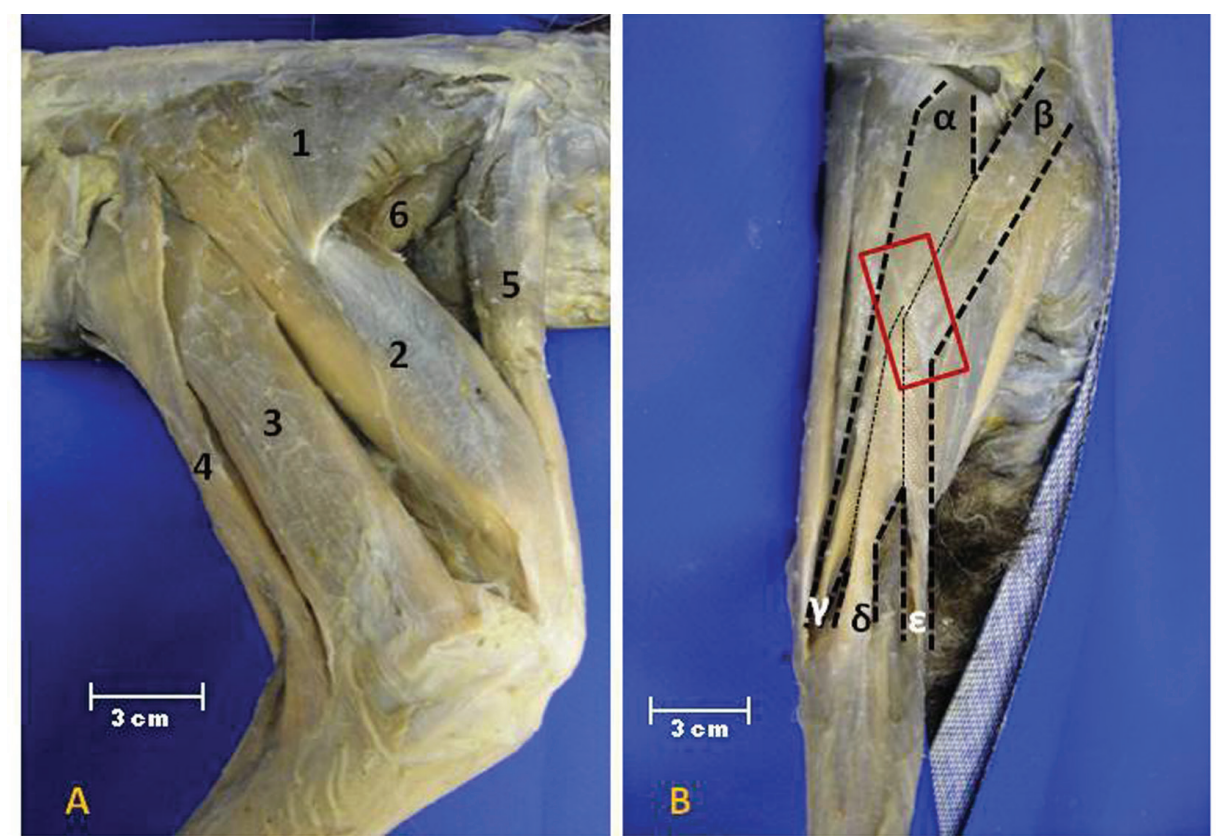

Figure 1. Muscles of the right pelvic limb of the Brazilian Common Opossum; A. Lateral view of the thigh; 1 - superficial gluteal muscle; 2 - quadriceps femoris muscle; 3 - biceps femoris muscle; 4 - semitendinosus muscle; 5 - sartorius muscle; 6 - iliopsoas; $B$. Caudal view of thigh. In detail the portions of the semitendinosus muscle and the connective tendon; $\alpha, \beta-$ origins; and $\gamma, \delta, \varepsilon-$ insertions of the semitendinosus muscle.

are known because they give births in early stages of development and invest in prolonged lactation [25].

The use of opossums in experimental studies on nervous system has been conducted since the 1970s $[3,9,39,40,43]$. Despite the abundance of morphological data of the opossum nervous system [16, $17,19,23,24,26,27,35,42]$, the anatomy of the lumbosacral plexus is not widely reported.

The aim of this study is to describe the lumbosacral plexus of the Brazilian Common Opossum and compare it with other species to support biomedical experiments on peripheral and central nervous system and provide zoological data.

\section{MATERIALS AND METHODS}

We used 10 pelvic limbs from 5 adult specimens ( 3 males and 2 females) of the Brazilian Common Opossum donated by Niteroi Zoo after death. The causa mortis were pulmonary infection (2), dog attack (1) and idiopathic (2). The specimens were fixed with $10 \%$ formalin by heart and muscular injections.

After classic anatomical techniques for dissection, the lumbosacral plexus was described from the origin in the spinal cord to peripheral innervations.

The Nomina Anatomica Veterinaria [44] was applied.

\section{RESULTS}

\section{Muscle anatomy}

The dissection of the pelvic limb muscles revealed the absence of the tensor fasciae latae muscle. Furthermore, we found a single sartorius muscle for each limb (Fig. 1A).

We also registered 5 portions -2 origins and 3 different insertions - in the semitendinosus muscle. Those portions were connected by a common tendon in middle third of the muscle (Fig. 1B).

\section{Lumbosacral plexus origins}

The lumbosacral plexus was formed by the ventral branches of the L3, L4, L5, L6 and S1 spinal nerves. These lumbar nerves combined to compose two trunks, L3-L4 and L4-L5-L6. The ventral branch of the $\mathrm{S} 1$ nerve did not compose any trunk (Fig. 2A).

\section{The nerves in general}

The L3-L4 trunk was the origin of the femoral, saphenous and obturator nerves (Fig. 2B). The ischiatic, cranial gluteal and caudal gluteal nerves had origin in the trunk L4-L5-L6 (Fig. 2B). The most caudal nerve of the lumbosacral plexus, the pudendal nerve, emerged 


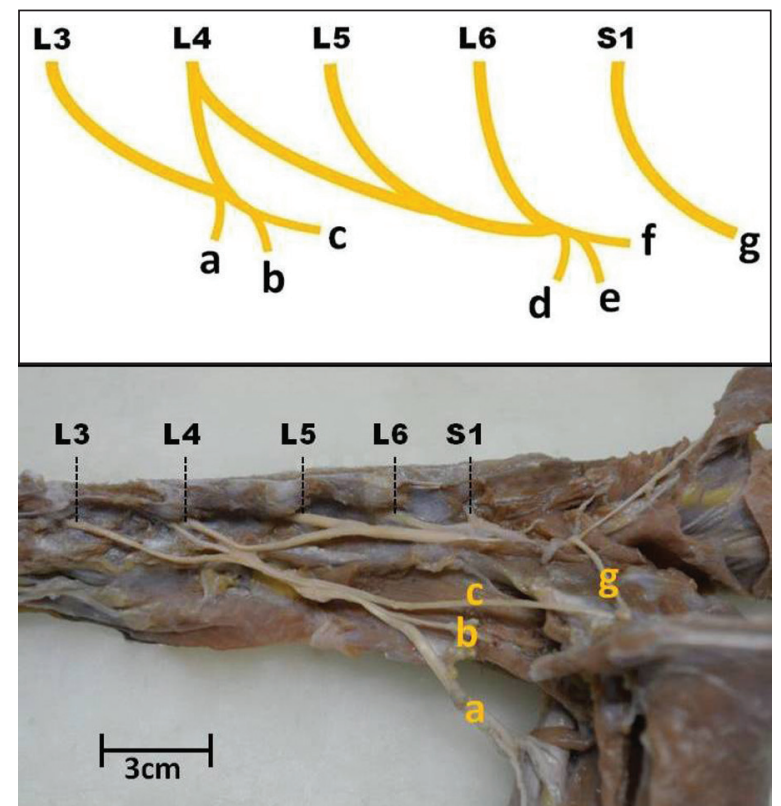

Figure 2. Scheme and macrophotograph of the lumbosacral plexus origin; L3-L6 and S1 - ventral branches of the spinal nerves; $a$ - femoral nerve; $b$ - saphenous nerves; $c$ - obturator nerve; $\mathrm{d}$ - cranial gluteal; $\mathrm{e}$ - ischiatic nerve; $\mathrm{f}$ - caudal gluteal nerve; $\mathrm{g}$ - pudendal nerve.

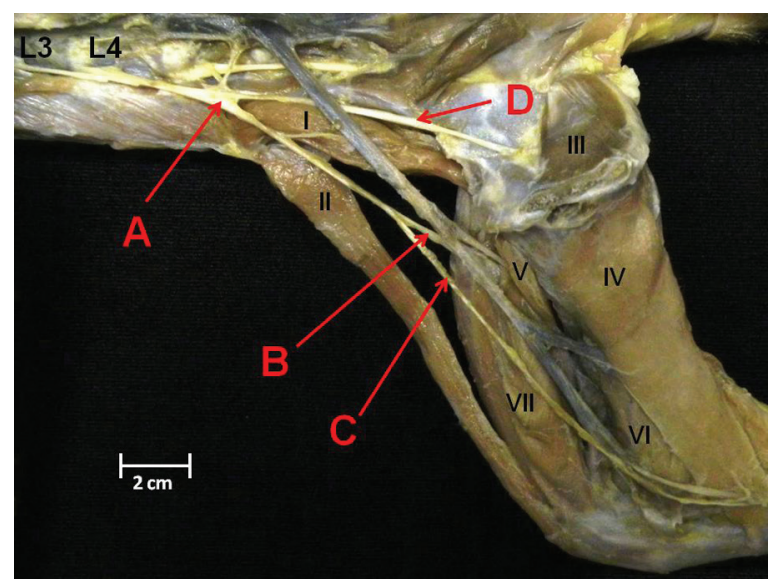

Figure 3. Medial view of the right pelvic limb of the Brazilian Common Opossum and nerves; I - iliopsoas muscle; II — sartorius muscle; III — internal obturator muscle; IV — gracilis muscle; $\mathrm{V}$ - pectineus muscle; $\mathrm{VI}$ — adductor muscle; $\mathrm{VII}$ — quadriceps femoris muscle; $\mathrm{A}$ - L3-L4 nerve trunk; $\mathrm{B}$ - femoral nerve; $\mathrm{C}$ - saphenous nerve; $\mathrm{D}$ - obturator nerve.

solely from the S1 ventral branch (Fig. 2B). We did not find any anatomical variation among the specimens.

\section{The femoral nerve}

After the origin, the femoral nerve ran ventrally and caudally, closely related to sub-lumbar muscles supplying the iliopsoas muscle. Then, the femoral nerve emerged on the medial surface of the thigh under the sartorius muscle. The nerve sent branches to the sartorius and quadriceps femoris muscles (Fig. 3).

\section{The saphenous nerve}

The saphenous nerve was closely related to the origin of the femoral nerve. The saphenous nerve supplied the sartorius muscle and ran distally on the medial surface of the thigh. The nerve spread under the skin of the dorsal region of the foot (Fig. 3).

\section{The obturator nerve}

The obturator nerve ran on the lateral margin of the pelvic cavity, penetrated and passed through the internal obturator muscle. Then, the nerve sent branches to muscles of the medial region of the thigh, the internal obturator, pectineus, adductor and gracilis muscles (Fig. 3).

\section{Ischiatic nerve}

The ischiatic nerve emerged from the major ischiatic foramen as the most robust nerve of the pelvic limb. The nerve ran caudally on the dorsal surface of the middle gluteal muscle. After the major trochanter of the femur, the ischiatic nerve turned distally and ran under the biceps femoris muscle. Around the middle third of the thigh, the ischiatic nerve was divided into two branches, the tibial nerve and the fibular nerve.

The ischiatic nerve supplied the biceps femoris, semitendinosus and semimembranosus muscle. The tibial nerve sent muscular branches to the caudal leg while the fibular nerve supplied the craniolateral leg (Fig. 4).

\section{Cranial gluteal nerve}

The cranial gluteal nerve arose from the major ischiatic foramen, ventrally to the ischiatic nerve. The cranial gluteal nerve ran distally and cranially, passed through the middle gluteal muscle and reached the superficial gluteal muscle. Both middle and superficial gluteal muscle were supplied by the cranial gluteal nerve (Fig. 4).

\section{Caudal gluteal nerve}

The caudal gluteal nerve emerged from the major ischiatic foramen dorsally to the ischiatic nerve. In its caudal direction run, the caudal gluteal nerve sent branches to supply respectively the middle gluteal, biceps femoris, gemelli and quadratus femoris muscle (Fig. 4). 


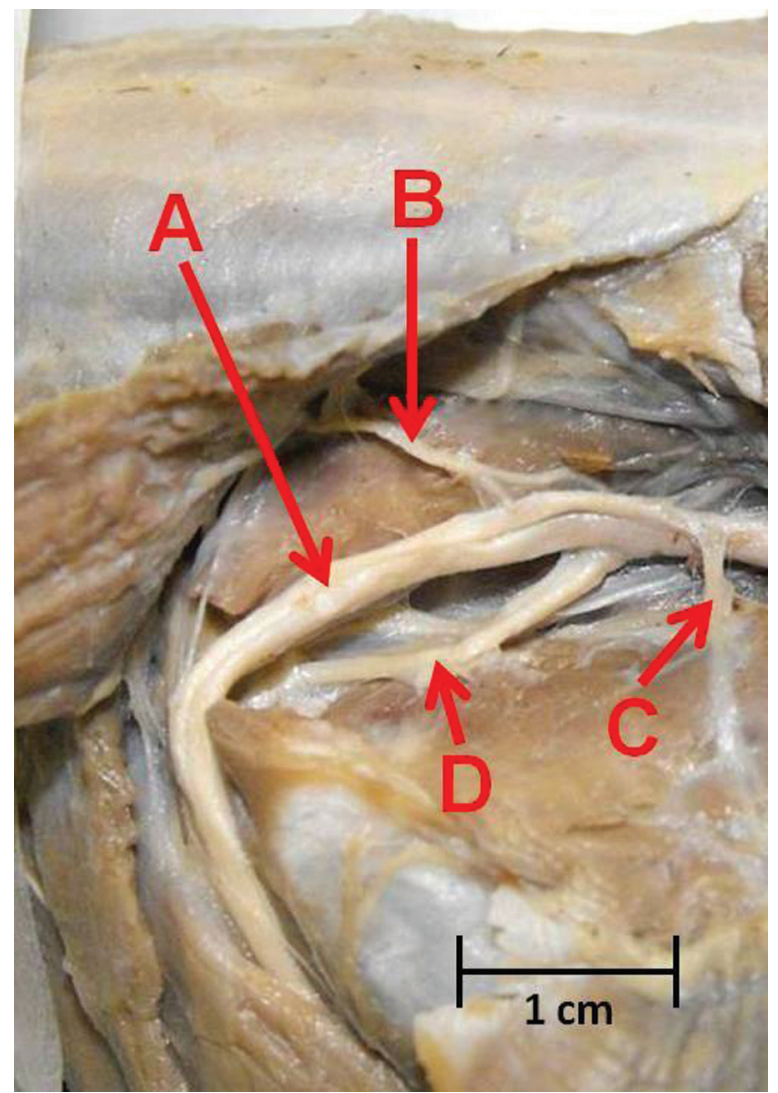

Figure 4. Gluteal region of the right limb of the Brazilian Common Opossum; A - ischiatic nerve; B - caudal gluteal nerve; $\mathrm{C}$ - cranial gluteal nerve; $\mathrm{D}$ - pudendal nerve.

\section{Pudendal nerve}

The pudendal nerve was observed emerging from the major ischiatic foramen. The nerve ran medially to the middle gluteal muscle and the vertebral head of the semitendinosus. The pudendal nerve was observed reaching external genital organs and perineal structures (Fig. 4).

\section{DISCUSSION}

The muscle results suggest that despite opossum has less refinement of flexing the hip joint and extending the stifle in comparison to other mammals, this trait has been advantageous for species perseverance. The Brazilian Common Opossum - from the Methatheria clade - did not present the tensor fasciae latae muscle, responsible for the above mentioned movements of the hip and stifle joints, contrary to the anatomy of many eutherian species, including laboratory animals, domestic animals and primates $[2,7,11,14,18,21,28,33,34]$. Furthermore, femoral mechanical loading in opossum is different from other eutherian species as reported in Didelphis virginiana. The mediolateral bending and torsion in femur is possibly a consequence of the anatomical characteristic, including the crouched position of the femur [15]. The findings presented in Brazilian Common Opossum are in agreement with former anatomical references for other opossum species [36].

Other notable findings were the distribution of the lumbosacral nerves that indicate variations in nerves position and muscle supply during species evolution. When comparing the Brazilian Common Opossum to eutherian species we noticed many differences in the nerve destination. This is in agreement with previous studies regarding the gluteal nerves distribution in other species [37]. This way, it is not correct to affirm that the nerve is an invariable structure of reference for muscle homology and homonym as reported previously $[29,36]$.

Regarding the uncommon position of the pudendal nerve, the results suggest a new possibility for experimental models on neural function for urinary and faecal studies. Using a simple surgical approach, it is possible to reach the pudendal nerve emergence from the major ischiatic foramen in the Brazilian Common Opossum. This makes it easy to transact or electrically stimulate the pudendal nerve and avoids difficult laminectomies and bone damage. In addition, the opossums do not have cecotrophic habits as found in rabbits which distress procedures affect species nutritional balances. This could be a great advance over the use of rats and rabbits with known models problems $[6,10,31]$.

\section{CONCLUSIONS}

The data revealed interesting differences between the Methateria and Eutheria clades for lumbosacral plexus distribution. It is possible to assume the Brazilian Common Opossum is a better model than other common laboratory species for pudendal nerve procedures. However, it is also important to consider other differences in the muscle innervation for procedures that affect, especially, the caudal gluteal nerve and sartorius muscle where species anatomical differences are more relevant.

New investigation using other species of opossums are necessary to best comprehend the lumbosacral plexus distribution in the Methatheria clade and to confirm that other opossum species are eligible as a good model for pudendal nerve studies. 


\section{Acknowledgements}

We thank Professor Dr Concepta Margaret McManus for revising this manuscript.

\section{REFERENCES}

1. Astúa de Moraes D, Santori RT, Finotti R, Cerqueira R (2003) Nutritional and fiber contents of laboratory established diets of Neotropical opossums (Didelphimorphia, Didelphidae). In: Jones M, Dickman C, Archer M eds. Predator with pouches: the biology of carnivorous marsupials. CSIRO Publishing, Melbourne, pp. 225-233.

2. Barone R, Pavaux C, Blin PC, Cuq P (1973) Atlas of Rabbit Anatomy. Masson \& Cie Éditeurs, Paris.

3. Barradas PC, Cavalcante LA (1998) Proliferation of differentiated glial cells in the brain stem. Braz J Med Biol Res, 31: 257-270.

4. Cáceres NC, Monteiro-Filho ELA (2000) The Common Opossum, Didelphis aurita, as seed disperser of several plants in Southern Brazil. Ciência e Cultura, 52: 41-44.

5. Carvalho FMV, Fernandez FA, Nessimian JL (2005) Food habitats of sympatric opossums coexisting in small Atlantic Forest fragments in Brazil. Mamm Biol, 70: 366-375.

6. Chen S-C, Grill WM, Fan W-J, Kou YR, Lin YS, Lai C-H, Peng C-W (2012) Bilateral pudendal afferent stimulation improves bladder emptying in rats with urinary retention. BJU Int, 109: 1051-1058.

7. Constantinescu GM, Constantinescu IA (2004) Clinical Dissection Guide for Large Animals. lowa State Press, lowa.

8. Cunha AA, Vieira MV (2002) Support diameter, incline, and vertical movements of four didelphid marsupials in the Atlantic Forest of Brazil. J Zool, 258: 419-426.

9. DiMarino AJ, Cohen S (1973) The adrenergic control of lower esophageal sphincter function. An experimental model of denervation supersensitivity. J Clin Invest, 52: 2264-2271.

10. Dong C, Gao W, Jia R, Li S, Shen Z, Li B (2013) Reconstruction of anorectal function through end-to-side neurorraphy by autonomic nerves and somatic nerve in rats. J Surg Res, 180: 63-71.

11. Evans HE, de Lahunta A (2010) Guide to the Dissection of the Dog. Saunders Elsevier, Saint Louis.

12. Fonseca GAB, Robinson JG (1990) Forest size and structure: competitive and predatory effects on small mammal communities. Biol Conserv, 53: 265-294.

13. Gardner AL (2005) Order Didelphimorphia. In: Wilson DE; Reeder DM. Mammal Species of the World: a taxonomic and geographic reference. John Hopkins University Press, Baltimore.

14. Getty R (1986) Sisson/Grossman Anatomia dos Animais Domésticos. Editora Guanabara Koogan SA, Rio de Janeiro.

15. Gosnell WC, Butcher MT, Maie T, Blob RW (2011) Femoral loading mechanics in the Virginia opossum, Didelphis virginiana: torsion and mediolateral bending in mammalian locomotion. J Exp Biol, 214: 3455-3466.

16. Haight JR, Neylon $L$ (1978) An atlas of the dorsal thalamus of the marsupial brush tailed possum, Trichosurus vulpecula. J Anat, 126: 225-245.

17. Haight JR, Neylon L (1978) The organization of neocortical projections from the ventroposterior thalamic complex in the marsupial brush-tailed possum, Trichosurus vulpecula: a horseradish peroxidase study. J Anat, 126: 459-485.

18. Hartman CG, Straus Jr WL (1965) The Anatomy of the Rhesus Monkey (Macaca mulatta). Hafner Publishing Co, New York.

19. Hokoc JN, Oswaldo-Cruz E (1978) Quantitative analysis of the opossum's optic nerve: an electron microscope study. J Comp Neurol, 178: 773-782.

20. Jugelski WJr, Forsythe W, Dahl Dk, Thomas Ld, Moore JA, Kotin P, Falk HL, Vogel FS (1974) The opossum (Didelphis virginiana Kerr) as a biomedical model. II. Breeding the opossum in captivity: facility design. Lab Anim Sci, 24:404-411.

21. Liebich HG, König HE, Maierl J (2011) Membros Pélvicos ou Posteriores (Membra Pelvina). In: König HE, Liebich HG. Anatomia dos Animais Domésticos Texto e Atlas. Artmed, Porto Alegre, pp. 235-302.

22. Lira PK, Fernandez FAZ, Carlos HSA, Curzio PL (2007) Use of fragmented landscape by three species of opossum in south-eastern Brazil. J Trop Ecol, 23: 427-435.

23. Martin GF, Beattie MS, Bresnahan JC, Henkel CK, Hughes HC (1975) Cortical and brain stem projections to the spinal cord of the American Opossum (Didelphis marsupialis virginiana). Brain Behav Evol, 12: 270-310.

24. Maruch SMG, Alves HJ, Machado CRS (1989) Sympathetic innervation of the reproductive organs of the male opossum, Didelphis albiventris (Lund, 1841). Acta Anat, 134: 257-262.

25. May-Collado L, Kilpatrick CW, Agnarsson I (2015) Mammals from "down under": a multigene species-level phylogeny of marsupial mammals (Mammalia, Methatheria). Peer J, 2015: e805.

26. McDonald AJ, Culberson JL (1986) Efferent projections on the basolateral amygdale in the opossum, Didelphis virginiana. Brain Res Bull, 17: 335-350.

27. McMenamin PG, Krause WJ (1993) Morphological observations on the unique paired capillaries of the opossum retina. Cell Tissue Res, 271: 461-468.

28. Netter FH (2011) Atlas de Anatomia Humana. Elsevier, Rio de Janeiro.

29. Nitschke T (1972) Zusammensetzung der oberflächlichen Gesäßmuskulatur in vergleichedn-anatomischer Betrachtung. Anat Histol Embryol, 1: 363-374.

30. Paiva MGS, Chaplin EL, Stobbe NS, Araújo FAP, Silva NRS (1992) Utilização de Didelphis marsupialis como animal de laboratório. Pesqui Agropecu Bras, 27: 213-216.

31. Peng C-W, Chen J-JJ, Cheng C-L, Grill WM (2008) Improved bladder emptying in urinary retention by electrical stimulation of pudendal afferents. J Neural Eng, 5: 144-154.

32. Pires AS, Lira P, Fernandez FAZ, Schittini GM, Oliveira LC (2002) Frequency of movements of small mammals among Atlantic Coastal Forest fragments in Brazil. Biol Conserv, 108: 229-237.

33. Popescu P, Rajtová V, Horák J (1992) A colour atlas of the anatomy of small laboratory animals: rabbit, the guinea pig. Mosby, London.

34. Popescu P, Rajtová V, Horák J (2002) A Colour Atlas of the Anatomy of Small Laboratory Animals: Rat, Mouse and Gold Hamster. Saunders, London.

35. Rocha-Rego V, Canteras NS, Anomal RF, Volchan E, Franca JG (2008) Architectonic subdivisions of the amygdalar complex of a primitive marsupial (Didelphis aurita). Brain Res Bull, 76: 26-35. 
36. Romer AS, Parsons TS (1985) Anatomia Comparada dos Vertebrados. Atheneu Editora São Paulo LTDA, São Paulo.

37. Senos R, Benedicto HG (2015) Gluteal nerves in Crabeating fox. J Morphol Sci, 31: 233-235.

38. Silva LD, Passamani M (2009) Mamíferos de médio e grande porte em fragmentos florestais no município de Lavras, MG. Revista Brasileira de Zoociências, 11: 137-144.

39. Terman JR, Wang XM, Martin GF (1997) Developmental plasticity of selected spinocerebellar axons. Studies using the North American opossum, Didelphis virginiana. Brain Res Dev Brain Res, 102: 309-314.

40. Terman JR, Wang XM, Martin GF (2000) Repair of the transected spinal cord at different stages of development in North American opossum, Didelphis virginiana. Brain Res Bull, 53: 845-855.
41. Vieira MV, Olifiers N, Delciellos AC, Antunes VZ, Bernardo LR, Grelle CEV, Cerqueira R (2009) Land use vs. fragment size and isolation as determinants of small mammal composition and richness in Atlantic Forest remnants. Biol Conserv, 142: 1191-1200.

42. Volchan E, Vargas CD, da Franca JG, Pereira Jr A, Da RochaMiranda CE (2004) Tooled for task: Vision in the Opossum. Bioscience, 54: 189-194.

43. Wang XM, Qin YQ, Xu XM, Martin GF (1994) Developmental plasticity of reticulospinal and vestibulospinal axons in the North American opossum, Didelphis virginiana. J Comp Neurol, 349: 288-302.

44. World Association of Veterinary Anatomists (2005) Nomina Anatomica Veterinaria. World Association of Veterinary Anatomists, Hannover, Columbia, Gent, Sapporo. 